\title{
Effect of Progesterone Versus Erythropoietin on Neurological Outcome after Traumatic Brain Injury
}

\author{
FATMA S. SHAALAN, M.Sc.; HALA M. EL-GENDY, M.D.; GHADA F. EL-BARADEY, M.D. and \\ MOHAMED E. AFANDY, M.D.
}

The Department of Anesthesiology and Surgical Intensive Care, Faculty of Medicine, Tanta University

\begin{abstract}
Background: Traumatic Brain Injury (TBI) is a global health problem. Preclinical trials in animals shows that early injection of progesterone after experimental TBI decreased brain edema, neuronal loss, and behavioral deficits. Erythropoietin (EPO) attenuates TBI due to its neuroprotective actions and its effect on erythropoiesis.
\end{abstract}

Aim of Study: The aim of this study was to evaluate the effect of progesterone hormone versus erythropoietin on neurological outcome of patients with moderate traumatic brain injury.

Material and Methods: The patients were randomly assigned to 3 equal groups ( 35 in each group). Group C (control): Standard care and treatment. Group P (progesterone): Standard care + progesterone $1 \mathrm{mg} / \mathrm{kg}$ IM and then once/12 hours for 5 consecutive days. Group E (erythropoietin): Standard care + EPO IV 40,000IU within $6 \mathrm{hr}$ of the time of injury. The modified Marshall CT scan classification: Was obtained at admission and day 7. GCS: Daily evaluations over the initial 14-day period, adverse experiences, surgical procedures, intracranial complications and intake \& output of fluids were recorded. Disability Rating Scale (DRS) were measured on admission and after 1 Mon., length of ICU \& hospital stay and complications were measured.

Results: There was statistically significant increase in GCS in group P compared to group C and E. There was statistically significant improvement in DRS in group $\mathrm{P}$ compared to group $\mathrm{C}$ and $\mathrm{E}$ on admission and after one month. There was statistically significant decrease in the length of ICU and hospital stay in group P compared to group $\mathrm{C}$ and $\mathrm{E}$.

Conclusion: Progesterone hormone and erythropoietin improved neurological outcome in moderate head injury patients in the form of improvement in GCS and DRS and decrease in the length of ICU and hospital stay with better outcome in progesterone in comparison with erythropoietin.

Key Words: Traumatic brain injury - Progesterone - Erythropoietin.

Correspondence to: Dr. Fatma S. Shaalan, The Department of Anesthesiology and Surgical Intensive Care, Faculty of Medicine, Tanta University

\section{Introduction}

TRAUMATIC Brain Injury (TBI) is a global health problem. Much progress has been made in developing therapies to treat these injuries, including free radical scavengers, anti-inflammatory and anti-apoptotic agents [1].

Progesterone is a potent neurosteroidal hormone which is synthesized within the central nervous system. Preclinical trials in animals shows that early injection of progesterone after experimental TBI decreased brain edema, neuronal loss, and behavioral deficits [2] . Erythropoietin (EPO) attenuates TBI due to its neuroprotective actions and its effect on erythropoiesis [3]. The aim of this study was to evaluate the effect of progesterone hormone versus erythropoietin on neurological outcome of patients with moderate traumatic brain injury.

\section{Material and Methods}

After approval of Ethical Committee, this study was carried out in Tanta University Hospital. Duration of this study was one year from June 2017June 2018. A written informed consent was obtained from patient's relatives all patients were identified by coded numbers to maintain their privacy.

105 patients with non-penetrating moderate traumatic brain injury (Glasgow Coma Score (GCS) 9-12) admitted to ICU, 16-60 years, primary traumatic injury $<24$ hours and expected to stay in ICU for more than 48 hours were included. Exclusion criteria were: Past history of thromboembolic event (like pulmonary embolism, and deep venous thrombosis), hypercoagulable state, pregnancy and 3 months postpartum, severe uncontrolled hypertension, ischemic heart disease within the past 12 months, fits in the last 3 months, end-stage renal 
failure, hemodynamic instability due to other associated major trauma (chest trauma, abdominal trauma, long bone fracture) and if the first dose of study drug could not be given in the first 24 hours of primary injury.

After head computerized tomography scanning, the patients were delivered to the Surgical Intensive Care Unit immediately or following surgical evacuation of an intracranial hematoma. Decision regarding surgical decompression was taken according to the mass effect noted in the CT and was individualized to each patient. All patients received the standard care and treatment based on the guidelines for the management of head injury of the American Association of Neurologic Surgeons [4] which includes: (Normovolemia to maintain mean arterial blood pressure $>80 \mathrm{mmHg}$, normothermia from 36.6 to $37.2^{\circ} \mathrm{C}$, normoglycemia to maintain blood sugar $70-110 \mathrm{mg} / \mathrm{dl}$, maintain the oxygen pressure at a minimum of $100 \mathrm{mmHg}$ and the carbon dioxide pressure at approximately $35 \mathrm{mmHg}$, seizure prophylaxis with phenytoin, gastric ulcer prophylaxis with ranitidine, mannitol was given to patients with CT having evidence of focal mass effect or diffuse edema. Furosemide was added to patients with midline shift $(>5 \mathrm{~mm})$ and electrolyte homeostasis was maintained).

The patients were randomly assigned according to sealed envelopes method to three equal groups (35 patients in each group). Group C (control group) 35 patients: Standard care and treatment. Group P (progesterone group) 35 patients: Standard care + progesterone was given at $1.0 \mathrm{mg} / \mathrm{kg}$ via intramuscular injection and then once per 12 hours for 5 consecutive days [5]. Group E (erythropoietin group) 35 patients: Standard care + Erythropoietin was received intravenous injection 40,000 International Units (IU) within 6 hours of the time of injury [6].

The waste materials were disposed according to parameters of Infection Control Unit in Tanta University Hospital.

The vital signs were monitored continuously at the bedside (body temperature, heart rate, respiratory rate, blood pressure and pulse blood oxygen saturation). Laboratory tests: Including hematology, the coagulation profile and clinical chemistry were performed daily for one week after injury. A urine pregnancy test was performed at enrollment for female patients (as necessary).

CT scan was obtained in all patients at admission and day 7 , and categorized according to the modified Marshall computerized tomography scan classification (Table 1) [5]. GCS [7]: Table (2) daily evaluations of neurologic status over the initial 14-day period was performed, adverse experiences, surgical procedures, intracranial complications and intake and output of fluids were also recorded. Neurologic outcome measurements: Disability Rating Scale (DRS) (Table 3) [7] was measured on admission and after one month. Length of ICU and hospital stay and complications e.g. seizures or development of deep venous thrombosis, development of pulmonary embolism and any other thrombotic events (all patients checked for complications which were recorded and managed).

Table (1): Modified Marshall computerized tomography scan classification.

\begin{tabular}{|c|c|}
\hline Score & Pathology \\
\hline • $\mathrm{I}$ & $\begin{array}{l}\text { - Intracranial pathology not visible on the computerized } \\
\text { tomography scan. }\end{array}$ \\
\hline • II & $\begin{array}{l}\text { - Cisterns present with shift }<5 \mathrm{~mm} \text {; lesions present, } \\
\text { but no high-density or mixed-density lesions }>25 \\
\mathrm{~cm}^{3} \text {, with bone fragments and foreign bodies. }\end{array}$ \\
\hline • III & $\begin{array}{l}\text { - Cisterns compressed or absent, shift }<5 \mathrm{~mm} \text {, with no } \\
\text { high-density or mixed density lesions }>25 \mathrm{~cm}^{3} \text {. }\end{array}$ \\
\hline • IV & $\begin{array}{l}\text { - Shift }>5 \mathrm{~mm} \text {, with no high-density or mixed-density } \\
\text { lesions }>25 \mathrm{~cm}^{3} \text {. }\end{array}$ \\
\hline$\cdot \mathrm{V}$ & - Any surgically evacuated lesion. \\
\hline$\cdot$ VI & $\begin{array}{l}\text { - High-density or mixed-density lesions }>25 \mathrm{~cm}^{3} \text { with- } \\
\text { out surgical evacuation. }\end{array}$ \\
\hline
\end{tabular}

Table (2): Elements of the Glasgow Coma Scale [7]

\begin{tabular}{llc}
\hline Action & Response & Score \\
\hline Eye opening & Spontaneous & 4 \\
& To voice & 3 \\
& To pain & 2 \\
& No & 1 \\
Best verbal response & Oriented & 5 \\
& Confused & 4 \\
& Inappropriate words & 3 \\
& Incomprehensive sound & 2 \\
Best motor response & None & 1 \\
& Obeys & 6 \\
& Localize pain & 5 \\
& Withdrawal to pain & 4 \\
& Flexor posture & 3 \\
& Extensor posture & 2 \\
& None & 1 \\
\hline
\end{tabular}

Table (3): Disability rating scale and categories.

Disability categories [8]

\begin{tabular}{ll}
\hline Total DRS & Level of disability \\
\hline 0 & None \\
1 & Mild \\
$2-3$ & Partial \\
$4-6$ & Moderate \\
$7-11$ & Moderately severe \\
$12-16$ & Severe \\
$17-21$ & Extremely severe \\
$22-24$ & Vegetative state \\
$25-29$ & Extreme vegetative state \\
\hline
\end{tabular}


Disability rating scale $[8]$

$$
\text { A- Eye opening: }
$$

(0) Spontaneous 0- Spontaneous: Eyes open with sleep/wake rhythms indicating active arousal mechanisms, does not assume awareness.

(1) To speech 1- To speech and/or sensory stimulation: A response to any verbal approach, whether spoken or shouted, not necessarily the command to open the eyes. Also, response to touch, mild pressure.

(2) To pain 2- To pain: Tested by a painful stimulus.

(3) None 3- None: No eye opening even to painful stimulation.

\section{B- Communication ability:}

(0) Oriented

(1) Confused

(2) Inappropriate

(3) Incomprehensible

(4) None
0- Oriented: Implies awareness of self and the environment. Patients able to tell you a) Who he is; b) Where he is; c) Why he is there; d) Year; E) Season; F) Month; g) Day; h) Time of day.

1- Confused: Attention can be held and patient responda to questions but responses are delayed and/or indicate varying degrees of disorientation and confusion.

2- Inappropriate: Intelligible articulation but speech is used only in an exclamatory or random way (such as shouting and swearing: No sustained communication exchange is possible.

3- Incomprehensible: Moaning, groaning or sounds without recognizable wors, no consistent communication signs.

4- None: No sounds or communications signs from patient.

\section{C- Motor response:}

(0) Obeying

(1) Localizing

(2) Withdrawing

(3) Flexing

(4) Extending

(5) None

0- Obeying: Obeying command to move finger on best side. If no response or not suitable try another command such as "move lips, "blink eyes," etc. Do not inslude grasp or other reflex responses.

1- Localizing: A painful stimulus at more than one site causes limb to move (even slightly) in an attempt to remove it. It is a deliberate motor act to move away from or remove the source of noxious stimulation. If there is doubt as to whether withdrawal or localization has occurred after 3 or 4 painful stimulations, rate as localization.

2- Withdrawing: Any generalized movement away from a noxious stimulus that is more than a simple reflex response.

3- Flexing: Painful stimulation results in either flexion at the elbow. Rapid withdrawal with abduction of the shoulder or a slow withdrawal with adduction of the shoulder. If there is confusion between flexing and withdrawing. Then use pinprick on hands.

4- Extending: Painful stimulation results in extension of the limb.

5- None: No response can be elicited. Usually associated with hypotonia. Exclude spinal transection as an expianation of lock of response: Be satisfied that an adequate stimulus has been applied.

\section{D- Feeding (cognitive ability only):}

Does the patient show awareness of how and when to perform this activity? Ignore motor disabilities that interfere with carrying out this function. (This is rated under level of functioning described below).

(0.0) Complete 0-Complete: Continously shows awareness that he knows how to feed and can convey unambiguous information that he knows when this activity shoulder occur.

(1.0) Partial 1-Partial: Intermittently shows awareness that he knows how to feed and/or can intermittently convet reasonably dearly information that he knows when the activity should occur.

(2.0) Minimal 2-Minimal: Shows questionable or infrequent awareness that he knows in a primitive way how to feed and/or shows infrequently by certain signs, sounds, or activities that he is vaguely aware when the activity should occur.

(3.0) None 3- None: Shows virtually no awareness at any time that he knows how to feed and cannot convey information by signs, sounds, or activity that he knows when the activity should occur.

E- Toileting (cognitive ability only):

Does the patient show awareness of how and when to perform this activity? Ignore motor disabilities that interfere with carrying out this function. (This is rated under level of functioning described below). Rate best response for toileting basec on bowel and bladder behavior.

(0.0) Complete 0-Complete: Continously shows awareness that he knows how to toilet and can convey unambiguous information that he knows when this activity shoulder occur.

(1.0) Partial 1- Partial: Intermittently shows awareness that he knows how to toilet and/or can intermittently convet reasonably clearly information that he knows when the activity should occur.

(2.0) Minimal 2- Minimal: Shows questionable or infrequent awareness that he knows in a primitive way how to toilet and/or shows infrequently by certain signs, sounds, or activities that he is vaguely aware when the activity should occur.

(3.0) None

3- None: Shows virtually no awareness at any time that he knows how to toilet and cannot convey information by signs, sounds, or activity that he knows when the activity should occur. 
F- Grooming (cognitive ability only):

Does the patient show awareness of how and when to perform this activity? Ignore motor disabilities that interfere with carrying out this function. (This is rated under level of functioning described below). Grooming refers to bathing, washing, brushing of teeth, shaving, combing or brushing of hair and dressing.

(0.0) Complete 0-Complete: Continously shows awareness that he knows how to groom self and can convey unambiguous information that he knows when this activity shoulder occur.

(1.0) Partial 1- Partial: Intermittently shows awareness that he knows how to groom self and/or can intermittently convey reasonably clearly information that he knows when the activity should occur.

(2.0) Minimal 2- Minimal: Shows questionable or infrequent awareness that he knows in a primitive way how to groom self and/or shows infrequently by certain signs, sounds, or activities that he is vaguely aware when the activity should occur.

(3.0) None 3- None: Shows virtually no awareness at any time that he knows how to groom self and cannot convey information by signs, sounds, or activity that he knows when the activity should occur.

G- Leval of functioning (physical, mental, emotional or social function):

(0.0) Completely independent

(1.0) Independent in special enviroment

0- Completely independent: Able to live as he wishes, requiring no restriction due to physical, mental, emotional or social problems.

1- Independent in special enviroment: Capable of functioning independently when needed requirements are met (mechanical aids).

(2.0) Mildly dependent-limited 2- Mildly dependent: Able to care for most of own needs but requires limited assistance due assistance (non-resid helper)

(3.0) Moderately dependentmoderate assist (person in home)

(4.0) Markedly dependentassist all major activitis, all time

(5.0) Totally dependent-24 hour 5- Totally dependent: Not able to assist in own care and requires 24-hour nursing care. nursing care

H- “Employability” (as a full time worker, homemaker, or student):

(0.0) Not restricted

0 - Not restricted: Can complete in the open market for a relatively wide range of jobs commensurate with existing skills, or can initiate, plan execute and assume responsibilities associated with homemaking; or can understand and carry out most age relevant school assignments.

(1.0) Selected jobs, competitive

1- Selected jobs, competitive: Can compete in a limited job market for a relaively narrow range of jobs because of limitations of the type described above and/or because of some physical limitations; or can initiate, plan, execute and assume many but not all school assignments.

(2.0) Sheltered workshop, noncompetitive

2- Sheltered workshop, non-competitive: Cannot compete successfully in a job market because of limitations described above and/or because of moderate or severe physical limitations; or cannot without major assistance initiate, plan, execute and assume responsibilities for homemaking; or cannot understand and carry out even relatively simple school assignments without assistance.

(3.0) Not employable

3- Not emplyable: Completly unemployable because of extreme psychosocial limitations of the type described above, or completely unable to initiale, plan, execute and assume any responsibilities associated with homemaking; or cannot understand or carry out any school assignments.

- The psychosocial adaptability or "employability" item takes into account overall cognitive and physical ability to be an employee, homemaker or student.

- This determination should take into account considerations such as the following:

1- Able to understand, remember and follow instructions.

2- Can plan and carry out tasks at least at the level of an office clerk or in simple routine, repetitive industrial situation or can do school assignments.

3- Ability to remain oriented, relevant and apporiate in work and other psychosocial situations.

4- Ability to get to and from work or shopping centers using private or public transportation effect vely.

5- Ability to deal with number concepts.

6- Ability to make purchases and handle simple money exchange problems.

7- Ability to keep track of time and appointments.

The primary objective of this study was to evaluate outcome as evidenced by Disability Rating Scale (DRS) which assess cognitive and functional impairment of the individual who suffered from the traumatic brain injury. The secondary objective was to monitor secondary complications like development of seizures, fresh development of mass effect in CT, development of areas of infarction, 
duration of hospitalization and mortality, DVT, pulmonary embolism, myocardial infarction, cardiac arrest and cerebrovascular events.

The sample size calculation is performed using EpI-Info 2002 software statistical package designed by World Health Organization (WHO) and by Centers for Disease Control and Prevention (CDC). The sample size is calculated as $\mathrm{N}>32$ was based on the following criteria: $95 \%$ confidence limit, $82 \%$ power of study, control-patient ratio is $1: 2$, expected difference of outcome between control and patients to be ranging from $50-80 \%$.

Statistical presentation and analysis was conducted by IBM SPSS V.24. Results were expressed as means \pm Standard Deviation (SD). Student paired $t$-test: For statistical analysis within the same group. ANOVA test: Used for comparison of parametric data (age, CT category and length of ICU \& hospital stay) between the three studied groups. Chi-square test for qualitative data (sex, diagnosis and complications). $p$-value $<0.05$ was considered significant.

\section{Results}

In this study, 118 patients were assessed for eligibility, 7 patients did not meet the inclusion criteria and 6 patients their guardians refused to participate in the study. 105 patients were randomized into three groups 35 patients in each one; control group (C), progesterone group (P), Erythropoietin group (E). Fig. (1).

The results of the present study showed no significant difference among the three studied groups as regard age, sex, diagnosis (Table 4) and CT (Table 5).

There was statistically significant increase in GCS in progesterone group in comparison to the other groups Fig. (2). There was statistically significant improvement in DRS in group $\mathrm{P}$ in comparison to the other groups Fig. (3). There was statistically significant decrease in the length of ICU and hospital stay (days) in group P in comparison to the other groups (Table 6).

Both drugs were safe and well tolerated with no significant side effects. As regard development of seizures and development of DVT there was no significant difference among the three studied groups (Table 7).

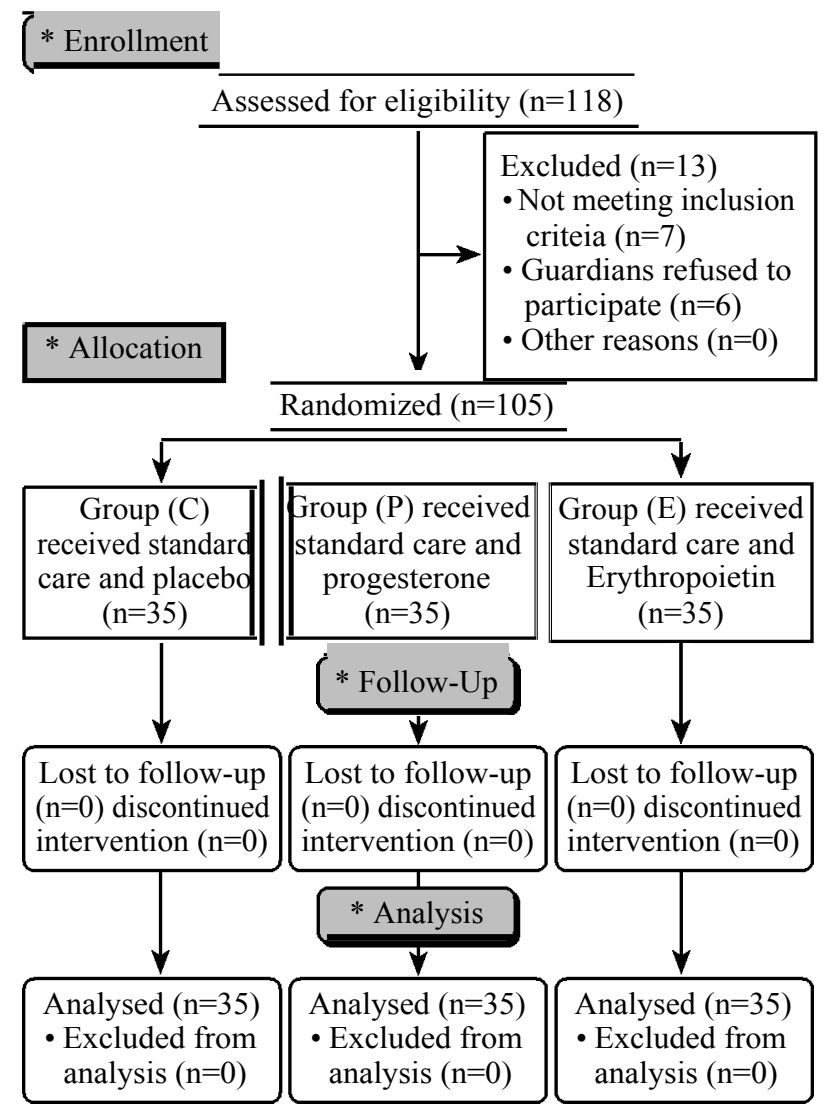

Fig. (1): Patient flowchart summarizing enrollment, allocation, follow-up and analysis in the study protocol.

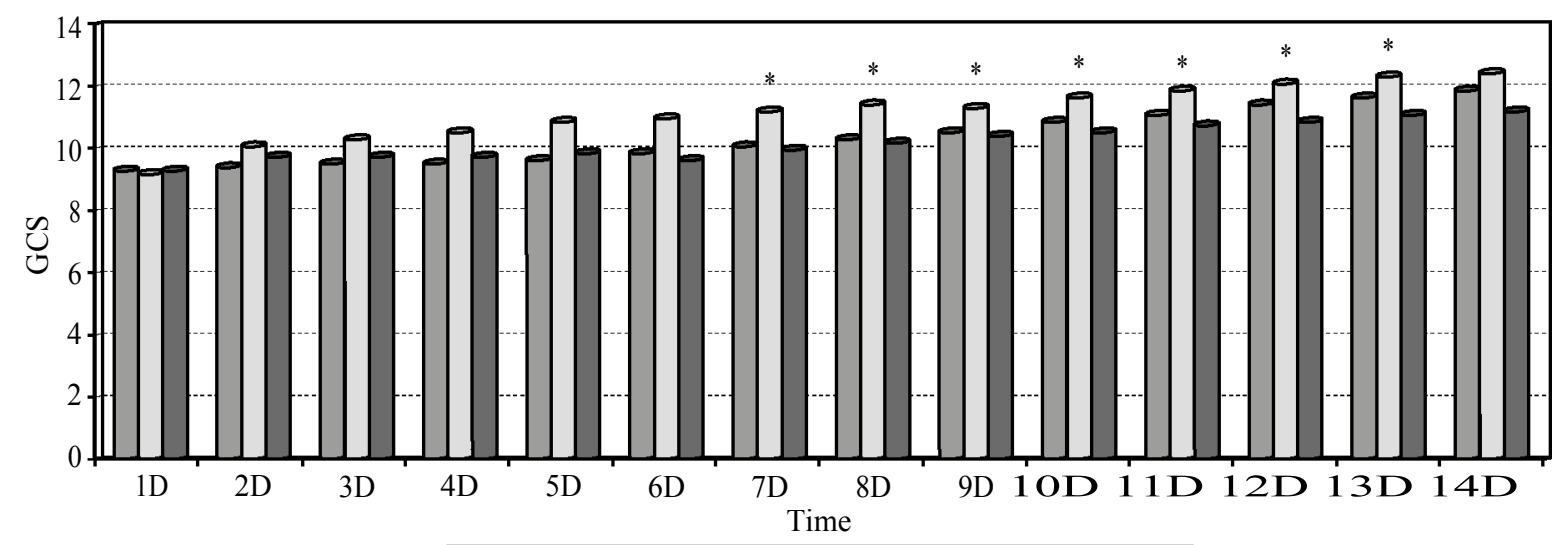

\begin{tabular}{|c|c|}
\hline Group C & Group P \\
\hline Fig. (2): Glasgow Coma Scale in the three groups.
\end{tabular}


Table (4): Demographic data and diagnosis in the three groups.

\begin{tabular}{llllll}
\hline & Group C & Group P & Group E & Test & $p$-value \\
\hline Age: & & & & \\
$\quad$ Range & $18-55$ & $17-56$ & $18-58$ & F: 0.161 & 0.852 \\
Mean \pm SD & $34.91 \pm 11.54$ & $35.49 \pm 11.70$ & $33.89 \pm 12.60$ & & \\
Sex: & & & & & \\
Male (\%) & $18(51.4 \%)$ & $16(45.7 \%)$ & $14(40 \%)$ & $\chi^{2}: 0.921$ & 0.631 \\
Female (\%) & $17(48.6 \%)$ & $19(54.3 \%)$ & $21(60 \%)$ & & \\
Diagnosis: & & & & & \\
EAH & $5(14.3 \%)$ & $7(20 \%)$ & $8(22.9 \%)$ & $\chi^{2}: 3.072$ & \\
SDH & $9(25.7 \%)$ & $8(22.9 \%)$ & $7(20 \%)$ & & \\
EDH & $7(20 \%)$ & $10(28.6 \%)$ & $8(22.9 \%)$ & & \\
ICH & $6(17.1 \%)$ & $4(11.4 \%)$ & $7(20 \%)$ & & \\
SAH & $8(22.9 \%)$ & $6(17.1 \%)$ & $5(14.3 \%)$ & & \\
\hline
\end{tabular}

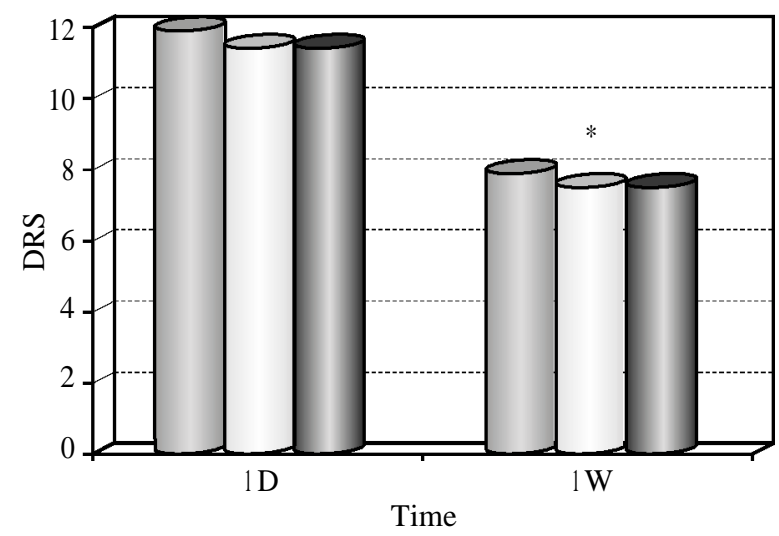

Group C

Group P

Group E

Fig. (3): Disability Rating Scale in the three groups.

Table (5): CT category on admission and at 1 week in all studied groups.

\begin{tabular}{lcclll}
\hline \multicolumn{1}{c}{ Range } & Mean \pm S.D & F-test $\boldsymbol{p}$-value \\
\hline CT 1D: & & & & & \\
Group C & $2-6$ & $4.17 \pm 1.32$ & 0.571 & 0.567 & $p_{1} 0.593$ \\
Group P & $2-6$ & $4.34 \pm 1.37$ & & & $p_{2} 0.288$ \\
Group E & $2-6$ & $4.51 \pm 1.34$ & & & $p_{3} 0.594$ \\
CT 1 W: & & & & & \\
Group C & $2-6$ & $4.03 \pm 1.32$ & 2.280 & 0.107 & $p_{1} 0.546$ \\
Group P & $1-6$ & $3.83 \pm 1.48$ & & & $p^{2} 0.144$ \\
Group E & $2-6$ & $4.51 \pm 1.34$ & & & $p_{3} 0.053$ \\
\hline
\end{tabular}

Table (6): Length of ICU and hospital stay (days) in the three groups.

\begin{tabular}{llllll}
\hline Length & Range & Mean \pm S.D & F-test $p$-value \\
\hline ICU: & & & & \\
Group C & $3-9$ & $5.83 \pm 1.27$ & 5.461 & $0.006^{*}$ & $p_{1} 0.002^{*}$ \\
Group P & $3-6$ & $4.8 \pm 0.96$ & & $p^{2} 0.282$ \\
Group E & $3-7$ & $5.49 \pm 1.17$ & \multicolumn{3}{c}{$p_{3} 0.033^{*}$} \\
Hospital: & \multicolumn{3}{c}{$0.010^{*}$} \\
Group C & $15-20$ & $18.43 \pm 1.67$ & 4.859 & $p_{1} 0.003^{*}$ \\
Group P & $14-20$ & $17.06 \pm 2.13$ & & $p^{2} 0.379$ \\
Group E & $14-20$ & $18.03 \pm 1.85$ & & $p_{3} 0.034^{*}$ \\
\hline
\end{tabular}

Table (7): Complication in three groups.

\begin{tabular}{llllll}
\hline Complications & Group C Group P & Group E & $\chi^{2}$ & $p$-value \\
\hline - Seizures & $3(8.6 \%)$ & $2(5.7 \%)$ & 0 & 2.943 & 0.230 \\
- DVT & 0 & 0 & $1(2.9 \%)$ & 2.023 & 0.364 \\
- Pulmonary & 0 & 0 & 0 & - & - \\
$\quad$ embolism & & & & & \\
- Deaths & 0 & 0 & 0 & - & - \\
\hline
\end{tabular}

\section{Discussion}

In the current study, the short-term effect of the drugs was evaluated by GCS and the mean values showed that there was a statistically significant improvement in group $\mathrm{P}$ compared to group $\mathrm{C}$ and $\mathrm{E}$ and in group $\mathrm{E}$ compared to group $\mathrm{C}$. The length of ICU and hospital stay that was statistically decrease in group $\mathrm{P}$ compared to group $\mathrm{C}$ and $\mathrm{E}$ and in group $\mathrm{E}$ in comparison to group $\mathrm{C}$.

As regard to the long-term effect of the drug was evaluated by DRS and the mean values showed that there was a statistically significant improvement in group $\mathrm{P}$ compared to group $\mathrm{C}$ and $\mathrm{E}$ and in group $\mathrm{E}$ compared to group $\mathrm{C}$.

These finding can be explained by progesterone has several features that make it an attractive potential drug candidate for TBI. Progesterone possesses pleiotropic effects that may markedly attenuate the injury cascade associated with TBI. Gene ontology analysis identified genes for progesterone low dose treatment involved in positive regulation of cell proliferation, innate immune response, anti-apoptosis, and blood vessel remodeling [9]. Progesterone reduces both vasogenic and cytotoxic edema after TBI. Progesterone can reduce lipid peroxidation through the inhibition of free radical formation and by enhancing scavenger efficiency to more vigorously eliminate reactive oxygen species by upregulating antioxidant enzymes, such as Superoxide Dismutase (SOD), and 
by increasing the levels of mitochondrial glutathione, a critical free radical scavenger [10].

As regard EPO, the mechanisms by which EPO exerts its effects on neuronal cells are not clearly understood. Proposed mechanisms included the ability of EPO to protect nerve cells from glutamate toxicity, reduce the immune response and inflammatory reaction, enhance nerve recovery, play a role in neurogenesis, prevent neuronal apoptosis, inhibit nitric oxide formation, and prevent oxidative stress. EPO is the endogenous cytokines of the central nervous system and play a neurotrophic and neuroprotective role [11].

In agreement, Xiao et al., [5] found that progesterone significantly improved the long-term effect of the drug in the form of Glasgow Outcome Scale (GOS) at 3 months in comparison to control group. Also, Wright et al., [12] showed improvement in DRS and decrease in mortality in progesterone group compared to placebo group after one month of injury in moderate and severe traumatic brain injury.

In agreement with our results as regard neuroprotective effect of EPO, Nirula et al., [13] found that Intravenous EPO was well tolerated in diffuse axonal injury and was associated with an improvement in patients' short term effect of the drug in the form of the length of ICU stay that was shorter in the EPO group. Also, Zhang et al., [14] found that EPO administration has been found to improve motor, sensory and cognitive function in experimental TBI and has also been shown to reduce lesion size and cell death after injury.

In disagreement, Skolnick et al., [15] who concluded that there is no clinical benefit of progesterone in patients with severe TBI (GCS $<8$ and at least one reactive pupil). GOS score at 1 and 6 months and mortality after 1 month did not differ significantly between the progesterone group and the placebo group. They included severe traumatic brain injury and about $8.8 \%$ of their patients had GCS of 3 and $44.3 \%$ had GCS of 4-6 compared to our study where we included moderate traumatic brain injury. They also used a different progesterone dose regimen (dosing began within 8 hours after injury at $0.71 \mathrm{mg} / \mathrm{kg}$ for one hour followed by 0.5 $\mathrm{mg} / \mathrm{kg} / \mathrm{hr}$ for 5 days).

In disagreement, Nichol et al., [6] concluded erythropoietin did not reduce the proportion of patients with a poor outcome (death, vegetative state, and severe disability) when compared with placebo: 134 (44\%) of 302 patients in the erythro- poietin group vs. 132 (45\%) of 294 in the placebo group.

Also, Robertson et al., [16] concluded that in patients with closed head injury, neither the administration of erythropoietin nor maintaining hemoglobin concentration of greater than $10 \mathrm{~g} / \mathrm{dl}$ resulted in improved the long-term effect of the drug in the form of the GOS score at 6 months. The transfusion threshold of $10 \mathrm{~g} / \mathrm{dl}$ was associated with a higher incidence of adverse events.

Both drugs were safe and well tolerated with no significant side effects. As regard to development of seizures and DVT, there was no significant difference among the three studied groups. Seizures occurred in $8.6 \%$ of the patients ( 3 patients) in group $\mathrm{C}$ as compared to $5.7 \%$ of the patients (1 patient) in group $\mathrm{P}$ and there were no seizures in group E. DVT occurred in only 1 patient $(2.9 \%$ of the patients) in group E and there was no DVT in group C \& P. There was no pulmonary embolism in the three studied groups.

This study has some limitations, first it was done on adults, brain injury is an enormous problem in pediatric age groups, but progesterone's effects on brain-injured children are unknown. Second, we used post-resuscitation GCS to screen patients for randomization. Clinicians know that a patient's GCS can fluctuate during the first few hours after a traumatic brain injury. It is possible, if not likely, that some patients classified as having a "moderate" TBI according to GCS score actually had a more severe injury, and some patients classified as "severe" on the basis of their index and had a more moderate injury. Third we did not measure serum progesterone level in progesterone group.

\section{Conclusion:}

Progesterone hormone and erythropoietin improved neurological outcome in moderate head injury patients in the form of improvement in GCS and DRS and decrease in the length of ICU and hospital stay with better outcome in progesterone in comparison with erythropoietin.

\section{Recommendations:}

Erythropoietin is in need for larger studies to assess its efficacy and potential complication of increase the risk of venous thromboembolism. We recommend that a separate trial will be needed to explore progesterone's safety and effectiveness as a treatment for brain-injured children and further large, multicenter clinical trials are needed to examine the ways in which progesterone is achieving the profound neurologic effect and to detect 
optimal conditions in which it can be used to improve the degree of neuroprotection.

\section{Conflicts of interest:}

No conflicts of interest declared.

\section{Authors' contributions:}

All authors had equal role in design, work, statistical analysis and manuscript writing.

\section{References}

1- NAZARIO J.: Hyperbaric oxygen therapy and promoting neurological recovery following nerve trauma. Undersea Hyperb. Med., 38 (5): 345-52, 2011.

2- KAORE S.N., LANGADE D.K., YADAV V.K., SHARMA P., THAWANI V.R. and SHARMA R.: Novel actions of progesterone: What we know today and what will be the scenario in the future? J. Pharm. Pharmacol., 64 (8): 1040$62,2012$.

3- KUMRAL A., TÜZÜN F., ONER M.G., GENÇ S., DUMAN N. and ÖZKAN H.: Erythropoietin in neonatal brain protection: The past, the present and the future. Brain Dev., 33 (8): 632-43, 2011.

4- PALMER S., BADER M.K., QURESHI A., PALMER J., SHAVER T., BORZATTA M., et al.: The impact on outcomes in a community hospital setting of using the AANS traumatic brain injury guidelines. J. Trauma Acute Care Surg., 50 (4): 657-64, 2001.

5- XIAO G., WEI J., YAN W., WANG W. and LU Z.: Improved outcomes from the administration of progesterone for patients with acute severe traumatic brain injury: A randomized controlled trial. Crit. Care, 12 (2): 61-8, 2008.

6- NICHOL A., FRENCH C., LITTLE L., HADDAD S., PRESNEILL J., ARABI Y., et al.: Erythropoietin in traumatic brain injury (EPO-TBI): A double-blind randomised controlled trial. Lancet, 386 (10012): 2499-506, 2015.

7- WALDER B., HALLER G., REBETEZ M.M.L., DELHUMEAU C., BOTTEQUIN E., SCHOETTKER P., et al.: Severe traumatic brain injury in a high-income country:
An epidemiological study. J. Neurotrauma, 30 (23): 1934 42, 2013.

8- CHUA K.S., NG Y., YAP S.G. and BOK C.: A brief review of traumatic brain injury rehabilitation. Ann. Acad. Med. Singapore, 36 (1): 31-42, 2007.

9- ANDERSON G.D., FARIN F.M., BAMMLER T.K., BEYER R.P., SWAN A.A., WILKERSON H.W., et al.: The effect of progesterone dose on gene expression after traumatic brain injury. J. Neurotrauma, 28 (9): 1827-43, 2011.

10- SUBRAMANIAN M., PUSPHENDRAN C., TARACHAND U. and DEVASAGAYAM T.: Gestation confers temporary resistance to peroxidation in the maternal rat brain. Neuroscience letters, 155 (2): 151-4, 1993.

11- SOLA A., WEN T.C., HAMRICK S.E. and FERRIERO D.M.: Potential for protection and repair following injury to the developing brain: A role for erythropoietin? Pediatric research, 57 (5 Pt 2): 110-7, 2005.

12- WRIGHT D.W., KELLERMANN A.L., HERTZBERG V.S., CLARK P.L., FRANKEL M., GOLDSTEIN F.C., et al.: ProTECT: A randomized clinical trial of progesterone for acute traumatic brain injury. Ann. Emerg. Med., 49 (4): 391-402, 2007.

13- NIRULA R., DIAZ-ARRASTIA R., BRASEL K., WEIGELT J. and WAXMAN K.: Safety and efficacy of erythropoietin in traumatic brain injury patients: A pilot randomized trial. Crit. Care Res. Pract., 2010: 1-5, 2010.

14- ZHANG Y., XIONG Y., MAHMOOD A., MENG Y., QU C., SCHALLERT T., et al.: Therapeutic effects of erythropoietin on histological and functional outcomes following traumatic brain injury in rats are independent of hematocrit. Brain Res., 1294: 153-64, 2009.

15- SKOLNICK B.E., MAAS A.I., NARAYAN R.K., VAN DER HOOP R.G., MacALLISTER T., WARD J.D., et al.: A clinical trial of progesterone for severe traumatic brain injury. N. Engl. J. Med., 371 (26): 2467-76, 2014.

16-ROBERTSON C.S., HANNAY H.J., YAMAL J.M., GOPINATH S., GOODMAN J.C., TILLEY B.C., et al.: Effect of erythropoietin and transfusion threshold on neurological recovery after traumatic brain injury: A randomized clinical trial. J.A.M.A., 312 (1): 36-47, 2014. 


\section{تآثير هرومون البروجيسترون مقارنة بالإريثروبويتين

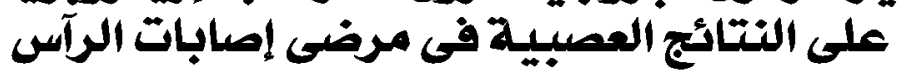

إصابات الرآس تعتبر مشكلة صحية عالمية وهناك كثير من الدراسات لمعالجة هذه الصدمات منها مضادات الإلتهابات. هرمون البرجستيرون

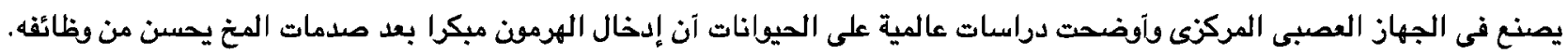

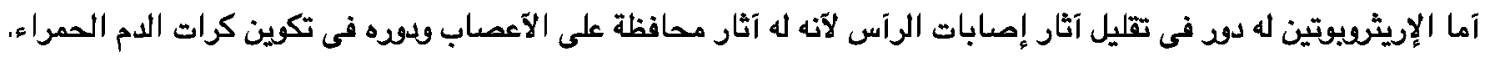

الهدف من العمل: كان الهلف من هذه الدراسة هوتقييم تآثير هرمون البرجستيرن والإيثربوتين على النتائج العصبية فى مرضى إصابات الرآس الحادة والمتوبسطة.

المرضى وطريق الدر اسـة: تم تصنيف المرضى بشكل عشوائى بإستخدام آظرف مختومة مغلقة إلى ثلاث مجموعات متساوية كل مجموعة خمسة وثلاثون مريض.

$$
\text { • مجموعة (آ): العلاج المتبع لهذه الحالة محلول ملح. }
$$

• مجموعة (ب): آخذت هرمون البرجيسترون بجرعة ا .+جم/كجم حقن عضلى ثم كل | I ساعة لمدة خمسة آيام متواصلة. • مجموعة (ج): آخذت الإريثرويوتين وديدى بجرعة . . . ع وحدة دولية في خلال 7 ساعات من وقت الإصابة. تم التخلص من النفايات وفقا لمعايير مكافحة العدوى فى مستشفيات جامعة طنطا.

ا- معدل الجلاسكو لقياس درجة الغيبوبة: كانت آعلى فى المجموعة ب مقارنة مع المجموعة آ و ج. Y- مقياس تصنيف الإعاقة: كان آثل فى المجموعة ب مقارنة مع المجموعة آ و ع ع.

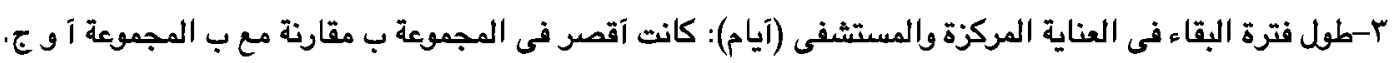

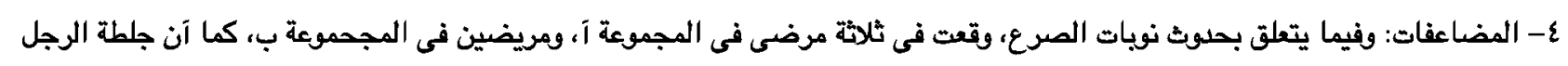

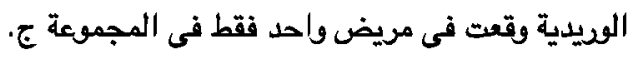

الخلاصدة: خلصنا إلى آن إستخدام هرمون البروجيسترن هو آفضل من إستخدام إريثربوتين لتصسين درجة الوعى فى إصابات الدماغ 